\title{
The Capitalist Labour Process: Concepts and Connections ${ }^{1}$
}

\section{Paul Thompson}

The Conference of Socialist Economists (CSE) and its subsequent journal Capital and Class were central in creating the conditions for a labour process debate in the UK. CSE's 1976 pamphlet, The Labour Process and Class Strategies, contained translated contributions from leading Italian Marxists such as Panzieri and Bologna. The first issue of the journal contained two articles which were to have an important role in early debates, one from the Brighton Labour Process Group (1977) and the other from Andy Friedman (1980). BLPG's contribution engaged with the ideas of Gorz (1976) and other French theorists, as well as with Braverman (1974).

Labour process theory (LPT), however, eventually became primarily associated with the annual labour process conference (ILPC - now in its $28^{\text {th }}$ year) and its extensive publishing programme (see http://www.ilpc.org.uk/). In the beginning, there was some overlap between these activities and Capital and Class/CSE. For example, the Cressey and MacInnes (1980) piece, Voting for Ford: Industrial Democracy and the Control of Labour, was a focal point for debate at the conference. As the ILPC became the dominant force in a number of academic disciplines focusing on work, the vital role played by CSE became under-appreciated and largely lost for most of the participants. Whilst Capital and Class continued to publish some articles on labour process issues, their connection to the wider mainstream debate was limited. This divergence was regrettable given the overlapping origins in a radical political economy tradition, but was probably inevitable as the different dynamics of the respective political and intellectual trajectories unfolded.

A common view is that the academic debate, having become mainstream (for a while), also became managerialist or managerialised by the mid-1980s, particularly as the conference was associated with radical academics in business schools. This is perhaps a little unfair. Studying management and managerial control is not in itself managerialist. However, the focus of research and debate did shift during and after 'second wave' contributions in the 1980s (see Thompson and Newsome 2004). The twin dominant skills and control debates, whatever useful findings generated, tended towards organisation-centric perspectives and a partial loss of the larger political economy picture. Things took a further turn for the worse during the 1990s with an outbreak of paradigm wars between rival camps within ILPC (see Special Issue of International Studies of Management and Organisation 2001). The ostensible focus was the so-called missing subject debate concerning the meaning and character of the subjective factor to the re/production of work relations. But in many respects these differences merely replayed the general conflict taking place between materialists and postmodernist across many disciplines concerning the relative significance of cultural and economic explanations. As these differences are philosophically and theoretically irresolvable, it was a relief when the post-modernists switched their attention to Critical Management Studies (see Thompson and O'Doherty 2009).

\footnotetext{
1 'The final, definitive version of this paper has been published in Capital and Class, Issue 100, Spring 2010 by SAGE Publications Ltd, All rights reserved. ๑ Paul Thompson.
} 
Despite this drift from some of the early theoretical and political concerns of LPT, we should not overplay the divergence between research emerging from mainstream labour process research and those of Capital and Class. Two key themes emphasise continuity. First, a shared critique of the conceptual flaws and empirical weaknesses underpinning post-Fordist theories. Whilst theoretical critiques played their part in emphasising the constraints and continuities with Fordist and neoFordist regimes of accumulation (add refs), a considerable body of qualitative case study research from the UK (Garrahan and Stewart 1992; Delbridge 1998; Danford 1999) and North America (Parker and Slaughter, 1988; Milkman 1997) combined to illustrate the 'dark side' of these lean production regimes. Drawing on second wave concepts of control, resistance and consent, such accounts emphasised the opportunities of new workplace regimes present to actively extend labour control. Later, labour process research would similarly be at the forefront of critical accounts of service and knowledge work, puncturing the myths of post-Fordist and knowledge economy perspectives (for an overview see Warhurst, Thompson and Nickson 2008).

Second, in contrast to claims of disappearing worker militancy and organisation from HRM and Foucauldian literatures, LPT articulated a defence and new articulation of labour agency. Though traditional emphasis was placed on the renewal of worker resistance, conceptual innovation aimed at expanding the conceptual and empirical repertoire of employee action focused on the idea of misbehaviour (Ackroyd and Thompson 1999). Though some more orthodox Marxists raised issues about a downgrading of collectivism (Lucio-Martinez and Stewart 1997), the idea built on the tradition of informal worker self-organisation in the spheres of effort, time and product, but added a new dimension around identity. Evidence that the perspective could be applied to collective worker mobilisation can be seen in Taylor and Bain's (2003) classic application to the use of humour in call centres. More generally, LPT has developed a perspective that retains the emphasis of preBraverman Italian theorists that class struggle is a key motor of workplace change, but distinguishes between capital and labour as workplace and societal actors.

Such a distinction can be found in the previously-referred to article by the BLPG: 'linked with the above, we should note that the relation between capital and labour at a general social level, cannot be derived from or reduced to the capital-labour relation within production' $(1977,23-4)$. The next section examines their arguments in more detail both as a way of engaging with early Capital and Class influences and addressing some substantive theoretical and empirical issues.

\section{The capitalist labour process: laws and lessons}

The key argument and claim of BLPG was that there are three 'immanent laws' of the capitalist labour process. These are defined as 'inherent' or 'basic structural features of the capitalist organisation of the labour process' $(1977,16)$, and said to be (i) the division of intellectual and manual labour (ii) hierarchy or hierarchical control (iii) fragmentation/deskilling of labour. The rationale for these claims is respectively that, capital has a monopoly on the knowledge and power over the design of production systems that results in an immanent division between conception and execution; hierarchy is the result of the inherently antagonistic nature of the CLP; and that deskilling is the outcome of the objective of capital to have labour functions that are calculable, standardisable routines.

One can raise principled objections to arguments for claims of law-like phenomena. Critical realists, referring to a distinctive social ontology, make a persuasive case that social scientists can only make 
claims about tendencies (Danermark et al 2002). But that would take us into a different debate. The main objection to these immanent laws is that they are empirically inaccurate and conceptually confused. There are divisions of intellectual and manual labour in the CLP, but the boundary shifts according to exogenous pressures and internal political struggles. Calling it inherent adds nothing to our capacity to explain such shifts. Hierarchy, as Weber and many other scholars have demonstrated, is not a structural feature specific to the CLP. Whilst hierarchical control is a feature at the general level of ownership relations, it is not necessary for detailed or operational control, where for example, capital may utilise delegated powers to teams and/or normative self-discipline (particularly amongst higher level employees). Finally, though calculable, standardisable routines are a frequently-observed feature of the CLP, they are not applicable to all forms of labour and deskilling may not even be the route to standardisation.

What actual labour process (and other) research shows us is that in the last 25 years there has been a significant drive by capital to access and valorise the tacit knowledge and skills of employees (Thompson, Warhurst and Callaghan 2001), as well as untapped dimensions of labour power such as emotions and corporeal qualities (Bolton 2005; Witz, Warhurst and Nickson 2003; Wolkowitz 2006). These are manifested in a variety of practices, including teamworking, knowledge management, emotional and aesthetic labour. Put bluntly, there is no way that an immanent law referring to a division between conception and execution and deskilling can adequately grasp these changes. Part of the problem for BLPG was that they stuck to closely to Marx's distinctions between formal and real subordination, and manufacture and machinofacture. In the first instance that led them to the empirically unsustainable argument that capital requires a monopoly of knowledge in and over production. Meanwhile, the second lead them to focus exclusively on industry in its traditional sense, neglecting the emergent service economy and its quite different forms of coordination and skill formation. BLPG were aware that 'Clearly, accurate knowledge of specific labour processes cannot be derived from consideration of the general form of the capitalist labour process' (1977, 23), hence the need to consider the mediating effects of political, industrial relations and other structures. But that is not an easily resolvable problem when dealing with 'immanent laws'.

\section{Core theory and core trends}

This choice of type and level of abstraction can be compared to the core LPT developed at the end of second wave theory (Thompson 1990; Edwards 1990; Thompson and Newsome 2004; Jaros 2005). The core starts from a recognition of the unique indeterminate character of labour as a commodity and thus the requirement for capital accumulation to convert labour power into actual profitable work. Four principles flow from this, the most relevant for the purposes of this article being:

- There is a logic of accumulation - arising from competition between capitalists and between capital and labour - that compels capital to constantly revolutionize the production of goods and services.

- Because market mechanisms alone cannot regulate the labour process, there is a control imperative as systems of management are utilized to reduce the indeterminacy gap. 
With respect to the first principle, whilst the logic places constraints on the willingness and ability of capital to dispense with hierarchical relations or fully combine conception and execution, there is no imperative to deskilling. The imperative is to cheapen the costs of labour, which in specific conditions, results in deskilling, whereas in others it may be to move into new branches of industry with more skilled labour power and generate surplus through greater innovation. Similarly, the control imperative cannot tell us, independently of the conditions of competition and the relations between capital and labour in a particular context, what the likely control strategy will be.

As Thompson and Smith (2009) argue, the central focus of LPT is on the nature and transformation of labour power under capitalism. With respect to this we can make some brief observations about key trends. Changes in work contexts and content means that employers are compelled to seek a more intensive utilization of labour power that I have described elsewhere as a qualitative intensification of labour. This includes the above mentioned moves towards accessing workers' tacit knowledge and skills, as well mobilising new sources of emotional and aesthetic labour.

Empowerment, or what Durand (2007) calls 'constrained involvement', thus comes with a price in terms of workload and effort bargain. This is neither conventional upskilling or deskilling, but a broader palette of skills and sources of labour power that capital is seeking from the modern worker,

These observations are consistent with wider evidence concerning work intensification and more demanding work Heery and Salmon, 2000; Burchell et al, 2002; Green 2006). An equally significant and related trend revealed in such studies is that intensity is linked to greater surveillance and performance targets. Even those employees undertaking more creative and knowledge intensive tasks are incorporated in this web of controls (that include knowledge management systems). The 2001 UK Skills Survey showed that the decline in task autonomy was at its sharpest among technical and professional employees (Felstead et al., 2004). At the same time, public-sector professionals have been increasingly subject to audit, targets and codes of conduct (Alvesson and Thompson, 2005). When allied to the spread of normative controls that reward compliance with behavioural rules and attitudes, we can observe a deepening and broadening of managerial controls within and across firms.

To some extent these trends are associated with the growth of high performance work systems, but not as we have been told or sold them. As I've argued elsewhere (Thompson and McHugh 2009), such practise have been based on the high performance from labour, but not the supporting employment system from capital. The reciprocity - workers investment more of themselves in return for investment in human capital - integral to HPWS (and incidentally post-Fordism) has either not materialised or dematerialised. We do not have rampant casualisation of the labour market (see Fevre 2007), a new form of work-related insecurity has developed based on a transfer of risk from capital to labour. Workers are told that they no longer have a job for life or even a career with a company; that they have to make themselves employable even without employment; while pensions are being cut-back or removed. Meanwhile, these very same 'high performance' practices generate overwork, time squeeze and 'negative job-to-home spillover' (Hogarth et al, 2000 plus ???). As labour power has become more elastic and demands seeped into the home sphere, individuals and families have had to absorb the costs of corporate restructuring and craft their own to craft makeshift solutions (Ackroyd et al 2005: 13). None of these trends are uncontested by labour, either formally or informally. Indeed, just as the sources of labour power expand so does the effort 
bargain, which now incorporates resistance around issues of emotions and newer dimensions of work (Callaghan and Thompson 2002; Bolton 2005).

\section{Political economy and the labour process: making better connections}

LPT has been good at charting such changes, less so at adequately explaining them. Explanation has focused on long-term trends towards flexible capitalism, the rise of a service-based economy, the persistence of lean production and now lean services, systemic rationalization in product and supply chains and more recently the development of financialization in the economy. The latter means that perpetual restructuring has been become the norm in most sectors as firms seek ways of cutting costs and managing assets to meet capital market requirements, resulting in management being unable to shield even core workers from the impacts and being largely unable to sustain local 'bargains' with the workforce.

One reason for the more general gap in explanation is the limitations of the idea of relative autonomy of the labour process that was part of core theory. Though reference would be made to various conditions of competition, too much research has been subordinated to a general focus on the labour process as work organisation- an empirical site of employment (Thompson and Smith 2009). What has been missing in a form of political economy that can be inserted between the generic, structural features of the capitalist labour process, as represented in the core theory, or indeed BLPG's 'immanent laws', and work relations.

Thompson and Vincent (forthcoming) argue that workplace-based case studies have tended to make use of a number of kinds of contextual framing: circuits of capital, regimes of accumulation and varieties of capitalism. Why not Marxist economic theory such as the law of value, labour theory of value, the tendency of the rate of profit to fall and so on? Some Marxist critics have indeed argued that LPT gives too much room to agents of capital (for instance, managers) to affect change and too little to value theory and the 'laws of motion' of capitalist society (e.g. Spencer 2000). However such critics do not demonstrate causal connections between the 'value theoretic approach' and actual outcomes in the labour process. Furthermore, prominent Marxists within the labour process debate do not use such concepts in their own work, suggesting that they have limited explanatory power in this context.

A further Marxist-sounding concept that surfaced in early critiques of the limits of existing LPT was 'circuits of capital'. Originally used by Kelly (1985) to refer to the need to consider competition between capitals as well as between capital and labour in production, the added value is an emphasis on the purchase of labour in labour markets and realisation of surplus value in product markets. This approach was applied in a small number of cases, including Peck (1990) in this journal. Asserting a preference for moving beyond the 'internal logic of the labour process', Peck examines competition dynamics in the clothing industry and their impacts on work relations. All this is entirely reasonable, but, other than the term itself, it is little different from what good case studies within LPT were already doing - that is locating their research inside the immediate conditions of competition (e.g. Edwards and Scullion 1982). .

A larger picture could have been supplied by regulation theory, with its concept of regimes of accumulation. Such regimes are constituted primarily by particular patterns of production, consumption, circulation and distribution, guided in turn through state-centred modes of regulation, 
encompassing various institutional structures (see Jessop for an overview). In practice regulation theory had a limited impact on UK-based LPT, primarily, I suspect because its ambitious attempt to link macro, meso and micro phenomena within a common framework jarred with it's preference for more loosely-coupled links between the workplace and political economy. What survived was more general references to concepts of accumulation regimes as types of capitalism, in debates on post/Fordism and more recently financialised capitalism.

Theoretical resources that imposed less conceptual rigidity could be found in the varieties of capitalism literature (Hall and Soskice 2001, Coates 2000). As a form of comparative political economy it relies primarily on stylised typologies of national economies. Given that some objects of LPT, such as skills formation systems, are embedded in specific labour market, education and industrial relations systems, it is hardly surprising that research sometimes utilised these frames. However, such institutional logics have limited explanatory power with respect to labour process dynamics, which are increasingly embedded within international production networks where the ability to coordinate and standardise work organisation and control systems constitutes a decisive competitive advantage. Such strategies and outcomes cannot be contained within national models that spend too much time on the variety and not enough on the capitalism.

Thompson and Vincent (2009) argue that a potentially more fruitful resource for (re)making the connections is value chain or global production network analysis. The former has a long and often limited history, but has emerged as a more developed means of understanding patterns of inter-firm coordination, dominance and governance across industry chains (Gereffi, Humphrey and Sturgeon 2005). Its emphasis on global chains escapes the limits of national models and its interest in the mechanisms of capturing value in the chain is potentially compatible with a radical political economy focus on capital accumulation. There is, however, a significant flaw - the analysis makes little or no room for the production of value in the labour itself - its focus is almost wholly on capital-capital relations. The issue is whether its conceptual tools can be bent towards incorporating capital-labour relations into the framework. Recent case studies examining restructuring processes across a variety of value chains from a perspective sympathetic to LPT suggest a potentially positive answer (Huws et al 2005; Thompson et al 2009).

\section{Final remarks}

As it ends its fourth decade, LPT faces a range of theoretical challenges. This article has focused on the challenge most consistent with the concerns of Capital and Class - restating and rearticulating the connections between capitalist political economy and the labour process. It has suggested that despite divergent trajectories, the projects associated with the ILPC and the journal have some overlapping origins, conceptual resources and concerns. LPT has contributed considerably to what we know about production systems and has been an important source of critique of new paradigm perspectives from flexible specialisation to the knowledge economy. What it has been less successful (along with other radical perspectives), has been systematic theory building on the back of this knowledge and critique. The main challenge is to develop multi-levelled analyses that can provide credible causal accounts of the relations between changing regimes of accumulation and patterns of change in the labour process within and across increasingly globalised industries. In recent years, the ILPC has itself gone global, with conferences in Europe (outside the UK) and for the first time in 
2010, in North America. New territories, resources and alliances offer positive prospects for addressing and resolving the theoretical and practical challenges that lie ahead.

\section{References}

Ackroyd, S., Batt, R., Thompson, P. and Tolbert, P. (2005) 'Texts and Times: Mapping the Changing Study of Work and Organizations', in Ackroyd, S., Batt, R., Thompson, P. and Tolbert, P. (eds.) The Oxford Handbook of Work and Organization, Oxford: Oxford University Press.

Ackroyd, S. and Thompson, P (1999) Organizational Misbehaviour London: Sage.

Alvesson, M., and Thompson, P. (2005). 'Post-Bureaucracy?', in S. Ackroyd, R. Batt, P. Thompson, and P. Tolbert, (eds) A Handbook of Work and Organization, Oxford: Oxford University Press.

Bolton, S. (2005). Emotion Management, London, Palgrave.

Braverman, H. (1974) Labor and Monopoly Capital, New York: Monthly Review Press.

Brighton Labour Process Group (1977) 'The Capitalist Labour Process', Capital and Class 1, 3-22.

Burchell, D. Ladipo, R. and Wilkinson, F. (eds) (2002) Job Insecurity and Work Intensification, London: Routledge.

Callaghan, G. and Thompson, P. (2002) 'We Recruit Attitude: The Selection and Shaping of Call Centre Labor', Journal of Management Studies, 39,2: 233-254.

Cressey, P., Maclnnes, J. (1980), 'Voting for Ford: Industrial Democracy and the Control of Labour', Capital and Class, Vol. 11 pp.5-37.

Danermark, B. Ekstrom. M, Jakobsen. L and Karlsson, J (2002). Explaining Society: Critical Realism in the Social Sciences. London: Routledge.

Danford, A. (1999) Japanese Management Techniques and British Workers London: Mansell.

Delbridge, R. (1998) Life on the Line in Contemporary Manufacturing, Oxford: Oxford University Press.

Durand, J-P. (2007) The Invisible Chain: Constraints and Opportunities in the New World of Employment, Basingstoke: Palgrave.

Edwards, P.K. (2005) 'The Challenging But Promising Future of Industrial Relations: Developing Theory and Method in Context-Sensitive Research' Industrial Relations Journal, 36, 4: 264-282.

Edwards, P. K. and Scullion, H (1982) The Social Organization of Industrial Conflict: Control and Resistance in the Workplace. Oxford: Blackwell. 
Felstead, A., Gallie, D. and Green, F. (2004) 'Job Complexity and Task Discretion: Tracking the Direction of Skills at Work in Britain', in C. Warhurst, I Grugulia and E. Keep (eds.) The Skills That Matter, London: Palgrave.

Friedman, A. (1977) ‘Responsible Autonomy and Direct Control’, Capital and Class 1: ??

Fevre, R. (2007) 'Employment Insecurity and Social Theory: the Power of Nightmares' Work, Employment and Society, 21, 3: 517-536.

Garrahan, P. and Stewart, P. (1992) The Nissan Enigma: Flexibility at Work in a Local Economy, London: Mansell.

Gereffi, G., Humphrey, J. and Sturgeon, T. (2005) 'The Governance of Global Value Chains', Review of International Political Economy, 12.1: 78-104.

Gorz, A. (1976) The Division of Labour: The Labour Process and Class Struggle in Modern Capitalism. Brighton: Harvester Press.

Green, F. (2006) Demanding Work: The Paradox of Job Quality in the Affluent Economy, New Jersey: Princeton University Press.

Heery, E. and Salmon, J. (eds) (2000) The Insecure Workforce, London: Routledge.

Jaros, S. (2005) 'Marxian Critiques of 'Thompson's (1990) "Core" Labour Process Theory: An Evaluation and Extension', ephemera, 5/1: 5-25.

Kelly, J. (1985) 'Add title' in Knights, D. et al. (eds) Job Redesign,London: Routledge:. 30-51.

International Studies of Management and Organization, Special Issue on the Labour Process Debate, 30 (4) pp 3 - 11, Winter $2000-2001$.

Jessop, B. (1990) 'Regulation Theories in Retrospect and Prospect', Economy and Society, 19.2: 153216.

Knights, D. and Willmott, H. (1990) (eds.) Labor Process Theory, London: Macmillan.

McKinlay, A. and Smith, C. (2009) (eds.) Creative Labour, Working in Creative Industries London: Palgrave.

Milkman, R. (1997) Farewell to the Factory: Auto Workers in the Twentieth Century Berkeley: University of California Press.

Spencer, D. (2000) 'Braverman and the Contribution of Labour Process Analysis to a Critique of Capitalist Production - 25 Years On', Work, Employment and Society 14: 223-243.

Martinez-Lucio, M. and Stewart, P. (1997) 'The Paradox of Contemporary Labour Process Theory: The Rediscovery of Labour and the Disappearance of Collectivism', Capital and Class 62: 49-77. 
Taylor, P. and Bain, P. (2003) 'Subterranean Worksick Blues: Humour as Subversion in Two Call Centres', Organization Studies, 24, 9: 1487-1509..

The Labour Process and Class Strategies. CSE Pamphlet, No.1, London: Stage 1, 1976.

Thompson P. (2003). 'Disconnected Capitalism: or Why Employers Can't Keep Their Side of the Bargain', Work, Employment and Society. 17.2: 359-378.

Thompson, P. and McHugh, D. (2009, $4^{\text {th }}$ edition) Work Organization, Basingstoke: Palgrave.

Thompson, P. and O'Doherty, D. (2009) 'Labor Process Theory and Critical Management Studies', M. Alvesson, T. Bridgman and H. Willmott (eds.) The Oxford Handbook of Critical Management Studies, Oxford: Oxford University Press.

Thompson, P., and Newsome, K. (2004) 'Labour Process Theory, Work and the Employment Relation' in B.E. Kaufman (ed) Theoretical Perspectives on Work and the Employment Relationship, Cornell: Cornell University

Press.

Thompson, P. Warhurst, C. and Callaghan, G. (2001) 'Ignorant Theory and Knowledgeable Workers: Interrogating the Connections Between Knowledge, Skills and Services', Journal of Management Studies, 38.7: 923-942.

Thompson, P. And Smith, C. (2009) 'Labour Power and Labour Process: Contesting the Marginality of the Sociology of Work', Sociology, October.

Thompson, P. and Vincent, S. (forthcoming) 'Beyond the Boundary: Labour Process Theory and Critical Realism', in P. Thompson and C. Smith (eds.) Working Life: Renewing Labour Process Analysis, Basingstoke: Palgrave.

Thompson, P. (1990). 'Crawling From the Wreckage: The Labour Process and the Politics of Production', D. Knights and H. Willmott (eds) Labour Process Theory, London: Macmillan.

Warhurst, C., Thompson, P. and Nickson, D. (2008) 'Labour Process Theory: Putting the Materialism Back into the Meaning of Service Work', in M. Korzcynski and MacDonald, C. (eds.) Service Work: Critical Perspectives, London: Routledge.

Witz, A., Warhurst, C. and Nickson, D. (2003) 'The Labour of Aesthetics and the Aesthetics of Organization', Organization, 10, 1, 33-54.

Wolkowitz, C. (2006) Bodies at Work, London: Sage. 